\title{
GROUNDWATER QUALITY ASSESSMENT AND MONITORING USING GEOGRAPHIC INFORMATION SYSYTEMS (GIS) IN PORT HARCOURT, NIGERIA ${ }^{*}$ NWANKWOALA, H.O, ${ }^{1}$ ELUDOYIN, O.S. ${ }^{2}$ and OBAFEMI, A. A. ${ }^{2}$ http://dx.doi.org/10.4314/ejesm.v5i4.S19
}

\author{
Received 22nd September 2012; accepted 30th October 2012
}

\begin{abstract}
The study evaluated the spatial variation of groundwater parameters in Port Harcourt metropolis using GIS. Thirty two (32) water samples were collected from boreholes from different parts of the study area into a treated and well labeled 1.5 litres plastic bootle. The water samples were then subjected to laboratory analysis for temperature, $\mathrm{pH}$, Calcium $\left(\mathrm{Ca}^{2+}\right)$, Chloride $(\mathrm{Cl})$, Total Dissolved Solids (TDS), Nitrate $\left(\mathrm{NO}_{3}^{-}\right)$, Sulphate $\left(\mathrm{SO}_{4}{ }^{2-}\right)$, Sodium $\left(\mathrm{Na}^{+}\right)$, Potassium $\left(\mathrm{K}^{+}\right)$, Magnesium $\left(\mathrm{Mg}^{2+}\right)$, Electrical Conductivity $(E C)$, Salinity, and bicarbonate $\left(\mathrm{HCO}_{3}^{-}\right)$. Global Positioning System (GPS) was used to record the latitudes and longitudes of the sampled boreholes. The result from the laboratory was subjected to descriptive statistical analysis in order to determine the mean, range and standard error of each parameter with the use of SPSS. Thereafter the result was imported to ArCGIS to generate the spatial variability maps for some groundwater parameters through the use of kriging in geostatistic module. Surfer 8 was used to generate the 2D and $3 D$ representation of the borehole depths while Idrisi for windows was used to generate the relationship between borehole depth and $\mathrm{pH}$; and borehole depth and $\mathrm{Ca}$. The result showed that $\mathrm{Cl}$ had the highest concentration among the anions with a mean value of $161.49 \mathrm{mg} / \mathrm{l}$ and Ca had the highest concentration among the cations with a mean value of 6.53 $\mathrm{mg} / \mathrm{l}$. The mean values of the all the groundwater parameters were lower than the WHO standard. Moderately weak inverse relationship was observed between the borehole depth and groundwater $\mathrm{pH}$ concentration; and between borehole depth and groundwater calcium concentration. It is recommended that the use of GIS should be encouraged to periodically monitor and assess groundwater quality.
\end{abstract}

Key words: Borehole, Groundwater, GIS, Geostatistics, Port Harcourt.

\section{Introduction}

Water is a valuable natural resource that is essential to human survival and the ecosystems health. Water comprises of coastal water bodies and fresh water bodies (lakes, river and groundwater) (Usali and Ismail, 2010). Groundwater resources is one of the most important resource available to humanity (Christophoridis et al., 2011), therefore it is more than necessary to provide a tool that can assess its quality over space. The principal goal of groundwater management in developing countries is to assess and manage the water resources that are available. Where groundwater is the main resource, management requires information on both its quantity and quality (Mogheir and Singh, 2002). Groundwater is an important part of the hydrologic cycle. It lies beneath the surface beyond the soil moisture root zone and it is tied to surface supplies through the soil moisture pores in soil and rock. Ground water is the largest potential fresh water source in the hydrologic cycle, larger than all surface lakes and streams combined (Christopherson, 2002). Between earth's land surface and a depth of $4 \mathrm{~km}(13,000 \mathrm{ft})$ worldwide, some $8,340 \mathrm{~km}\left(2,000,000 \mathrm{~m}^{3}\right)$ of water resides in a volume comparable to 70 times all the fresh water in the world (Christopherson, 2002).

The variation in the water parameters over space and time has a correlation to the land use dynamics and this involves many factors. Tripathy and Jothimani (2000) submitted that the rise in human population exploits more of natural resources and this is met through the growth of industries specifically chemicals and petrochemicals, urbanization, deforestation and intensive agricultural practices. Usali and Ismail (2010) observed that since the past few decades, the increasing of anthropogenic activities especially in 
industrial area has effects to water bodies. For instance, the use of chemicals in the crops for improved yield/production and discharge of waste from the industries contaminates ground water through percolation. These sporadic degrading activities have lead to gradual deterioration in the quality of surface and subsurface water. The loss of quality is causing health hazards and death of human, livestock and death of aquatic lives, crop failure and loss of aesthetics (Usali and Ismail, 2010).

Groundwater quality monitoring introduces the need to manage vast volumes of analytical data, interacting under elaborate physico-chemical laws. GIS techniques facilitate integration and analysis of large volumes of data, whereas field studies help to further validate results (Krishnamurthy et al., 1996; Saraf and Choudhury, 1998; Solomon and Quiel, 2006). Generally, GIS is defined as a complex computer system for the input, storage, management, analysis, modeling and mapping of digital spatial information (Dangedorf, 2001). In connection with modern information technology GIS enable new forms of communication between people, not only in the fields of research but also in entire communities (Twigg, 1990; Goodchild, 2000). Aral and Maslia (1996) demonstrated the utility of GIS applications for the analysis of the human exposure to contaminated drinking water. The contamination, related to volatile organic compounds (VOC's) in groundwater reservoirs, was distributed in the supply network. The extent of contamination and location of exposed population could be estimated through GIS tools. The input of demographic and epidemiological data into the GIS linked with water quality modeling provided new insights in spatial disease patterns (Dangedorf, 2001).

Database and GIS systems are important and powerful tools for representing and analyzing real life phenomena, in which the spatial dimension plays an important role. Their success is based to a large extent on data independence, genericity of the data manipulation language, and powerful output production possibilities (Tripathy and Jothimani, 2000). Data independence is the characteristic by which internal system features like implementation of data structures, is hidden from the users, who possibly perceive 'their' data in ways unrelated to actual storage techniques. Genericity of the manipulation language allows using the same language for completely different applications, and this is mainly achieved through a level of declarativeness that goes hand in hand with data independence. However, it is noted today, with the advancement of science and technology, the population, industries, agriculture activities, and urban development have grown up in Port Harcourt metropolis.

The domestic sewage factories effluents, and agriculture waste can lead to deterioration of ground water quality. Thus, the groundwater quality monitoring and assessment is needed in order to raise awareness of public to the consequences of present and future threats of contamination to groundwater resources. This study therefore evaluates the variation in the ground water parameters in Port Harcourt Metropolis using GIS.

\section{Materials and Methods \\ Study Area}

The study area is Port Harcourt metropolis (Figure 1). It lies on latitudes $04^{\circ} 47^{\prime}$ and $04^{\circ}$ $54^{\prime}$ North and longitudes $06^{\circ} 54^{\prime}$ and $07^{\circ} 40^{\prime}$ East and enjoys a tropical monsoon climate with lengthy and heavy rainy seasons from April to October ranging from $2000 \mathrm{~mm}$ to $2500 \mathrm{~mm}$ and very short dry seasons. The temperature is high all the year round and a relatively constant high humidity (IIoeje, 1972). The study area is influenced by urbanization or urban sprawl whereby smaller communities have merged together and form megacity. The reason is due to high influx of people resulting to rapid growth of the population size in the study area due to the expansion of oil and gas industries. The soil is usually sandy or sandy loam underlain by a layer of impervious pan and is always leached due to the heavy rainfall experienced in this area. The study area is well drained with both fresh and salt water. The salt water is caused by the intrusion of sea water inland, thereby making the water slightly salty. The relief is generally lowland. The vegetation found in this area includes raffia palms, thick mangrove forest and lowland tropical rain forest. 


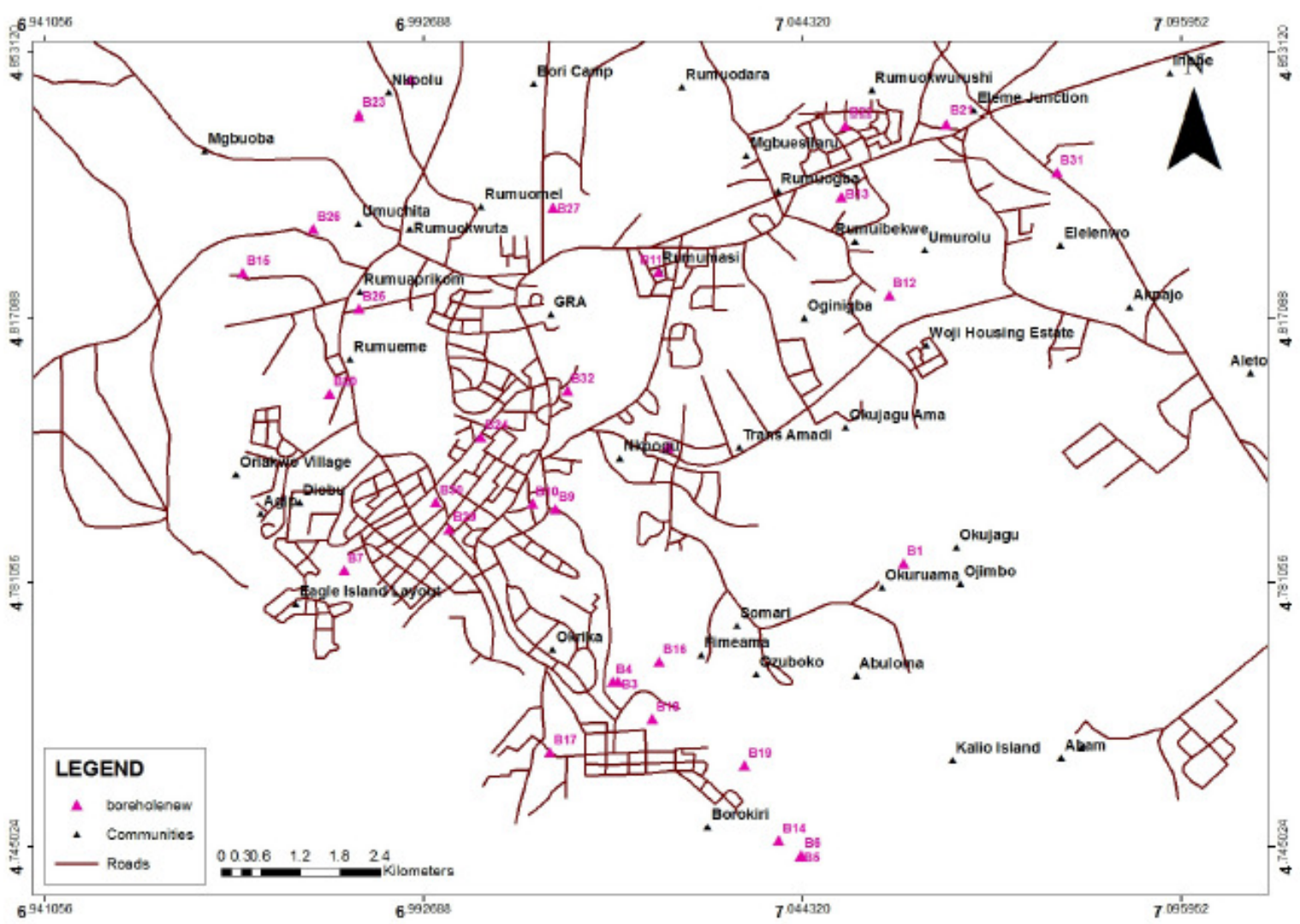

Figure 1 Map of Study Area showing the Location of Sampled Boreholes

\section{Sample Collection}

This study involved the use of primary data by collecting water samples from boreholes within Port Harcourt metropolis. Water samples were collected from thirty two boreholes across the study area (Figure 1) into a well-labeled polyethylene bottles. The bottles were properly rinsed with the borehole water to be sampled before the main water sample was collected in order to avoid contamination. Water samples were then subjected to laboratory analyses on both the cations and anions. The considered cations included Calcium $\left(\mathrm{Ca}^{2+}\right)$, Magnessium $\left(\mathrm{Mg}^{2+}\right)$, Sodium $\left(\mathrm{Na}^{+}\right)$, Potasium $\left(\mathrm{K}^{+}\right)$while the anions included Cholride $\left(\mathrm{Cl}^{-}\right)$, Bicarbonate $\left(\mathrm{HCO}_{3}{ }^{-}\right)$, Nitrate $\left(\mathrm{NO}_{3}{ }^{-}\right)$and Sulphate $\left(\mathrm{SO}_{4}{ }^{2-}\right)$. Properties such as electrical conductivity (EC) $\mathrm{pH}$, temperature and total dissolve solids (TDS) were also analyzed. Analyses of groundwater samples were carried out using standard methods (APHA1989; Nwankwoala and Udom, 2011). Cations were analysed using an
Atomic Absorption Spectrophotometer (Perkin - Elemer AAS 3110) and the anions using the Colorimetric method with the UV- Visible Spectrophotometer WPAS 110. Standard solutions and blanks were commonly run to check for possible errors in the analytical procedures. Generally, the processes controlling the chemistry of the groundwater were identified by the systematic study of hydro-chemical data. Global Positioning Systems (GPS) was used to record the latitudes and longitudes of each sampled borehole. The location readings enabled the mapping of the boreholes in their respective locations. Geostatisctics method through kriging module in ArcGIS 9.2 was used to generate the groundwater variability map of each considered water parameter across the study area. In addition, Surfer 8 was used to generate the $2 \mathrm{D}$ and $3 \mathrm{D}$ representation of the borehole depths and Idrisi of windows was used to analyze the relationship exhibiting 


\section{Results and Discussion}

\section{Chemical Composition of Groundwater}

Table 1 Chemical Composition of Groundwater Samples

\begin{tabular}{llll}
\hline Parameters & Range & Mean \pm S.E. & WHO(2006) Standards \\
\hline Temperature $\left({ }^{\circ} \mathrm{C}\right)$ & $26.33-29.64$ & $27.66 \pm 0.16$ & NS \\
pH & $3.84-7.72$ & $6.17 \pm 0.17$ & $6.5-8.5$ \\
$\mathrm{EC}(\mu \mathrm{S} / \mathrm{cm})$ & $28.00-717.40$ & $245.76 \pm 39.04$ & 500 \\
$\mathrm{TDS}(\mathrm{mg} / \mathrm{l})$ & $12.60-401.00$ & $145.49 \pm 21.15$ & 500 \\
$\mathrm{Cl}(\mathrm{mg} / \mathrm{l})$ & $12.00-710.00$ & $161.49 \pm 30.26$ & 250 \\
$\mathrm{SO}_{4}^{2-}(\mathrm{mg} / \mathrm{l})$ & $0.00-230.11$ & $68.77 \pm 9.31$ & 250 \\
$\mathrm{Salinity}^{-}(\mathrm{ppt})$ & $10.00-672.75$ & $142.41 \pm 27.09$ & $\mathrm{NS}$ \\
$\mathrm{NO}_{3}^{-}(\mathrm{mg} / \mathrm{l})$ & $0.00-34.00$ & $3.24 \pm 1.19$ & 50 \\
$\mathrm{HCO}_{3}^{-}(\mathrm{mg} / \mathrm{l})$ & $0.00-58.04$ & $16.67 \pm 2.29$ & $\mathrm{NS}$ \\
$\mathrm{Ca}^{2+}(\mathrm{mg} / \mathrm{l})$ & $2.00-18.30$ & $6.53 \pm 0.62$ & 7.5 \\
$\mathrm{Na}^{+}(\mathrm{mg} / \mathrm{l})$ & $0.21-3.45$ & $1.58 \pm 0.17$ & 200 \\
$\mathrm{Mg}^{2+}(\mathrm{mg} / \mathrm{l})$ & $0.23-8.90$ & $3.16 \pm 0.41$ & 50 \\
$\mathrm{~K}^{+}(\mathrm{mg} / \mathrm{l})$ & $0.04-0.89$ & $0.47 \pm 0.04$ & 200 \\
\hline
\end{tabular}

(NS: Not Stated)

The chemical composition of groundwater sample is shown in Table 1 above. The mean value of temperature was $27.66{ }^{\circ} \mathrm{C}$ with a range between $26.33{ }^{\circ} \mathrm{C}$ and $29.64{ }^{\circ} \mathrm{C}$ while the mean value of $\mathrm{pH}$ was 6.17 suggesting that the ground water was slightly acidic. Thus, the concentrations of $\mathrm{pH}$ in some communities within the study area were within the acceptable range of WHO standard. This may be due to the gas flaring in the Niger Delta region of Nigeria. Comparing the $\mathrm{pH}$ value with World Health Organization (WHO) standard value, the groundwater $\mathrm{pH}$ was below the range. The method of base-exchange method with dolomite should be adopted to treat the water especially in the areas where the $\mathrm{pH}$ was less than 6.5 (Nwankwoala and

Udom, 2011). This makes the water more potable for domestic use. Among the cations, Calcium $\left(\mathrm{Ca}^{2+}\right)$ dominated with a mean value of $6.53 \mathrm{mg} / \mathrm{l}$ while Chloride $\left(\mathrm{Cl}^{-}\right)$was the highest among the anions. The mean values of all the groundwater parameters in the area were lower than the WHO standard suggesting that the groundwater is not highly mineralized. Though based on the individual borehole, EC, $\mathrm{Cl}^{-}$and $\mathrm{Ca}^{2+}$ in some areas were higher than the WHO standard (Table 2). Figures 2 and 3 and Table 2 show that the ratio of the cations $\left(\mathrm{Na}^{+}, \mathrm{K}^{+}, \mathrm{Ca}^{2+}\right.$ and $\left.\mathrm{Mg}^{2+}\right)$ and anions $\left(\mathrm{HCO}_{3}{ }^{-}\right.$, $\mathrm{NO}_{3}{ }^{-}, \mathrm{SO}_{4}^{2-}$, and $\left.\mathrm{Cl}^{-}\right)$. The concentrations of these ions are in the following order: $\mathrm{Ca}>\mathrm{Mg}>\mathrm{Na}>\mathrm{K}=\mathrm{Cl}>\mathrm{SO}_{4}>\mathrm{HCO}_{3}>\mathrm{NO}_{3}$.

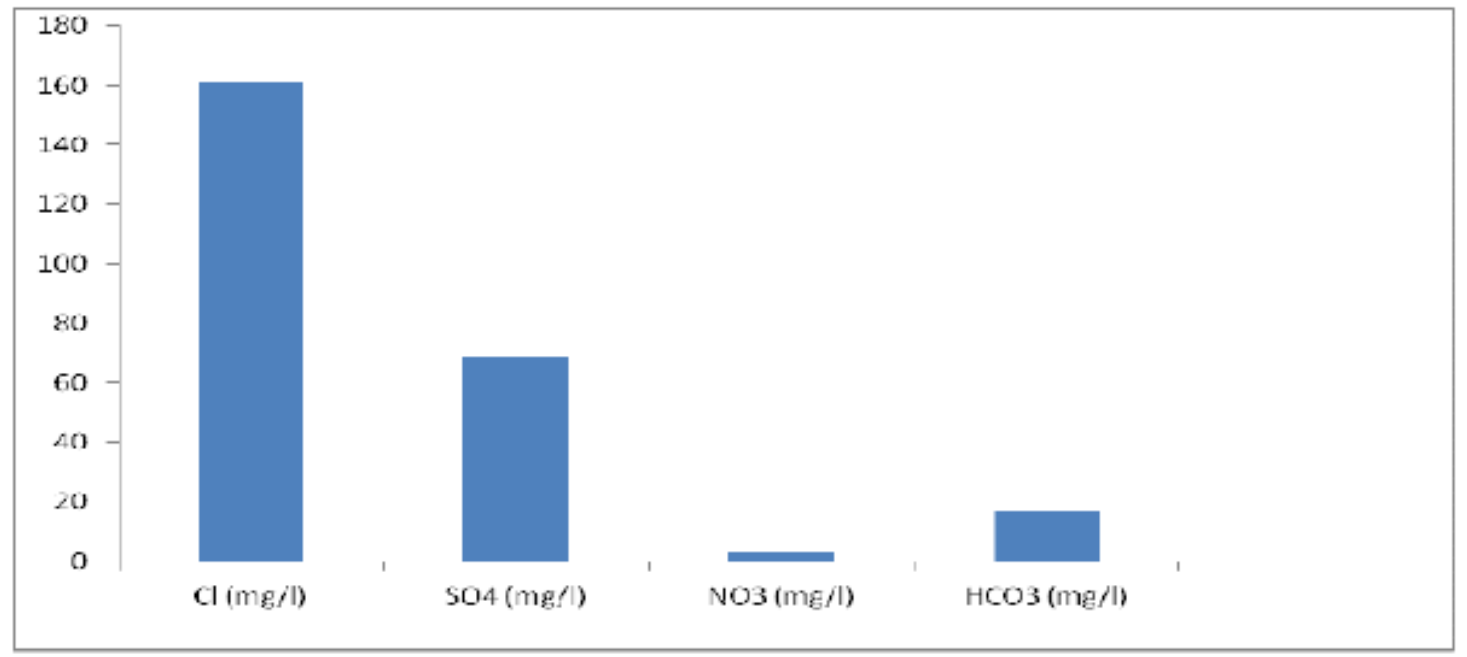




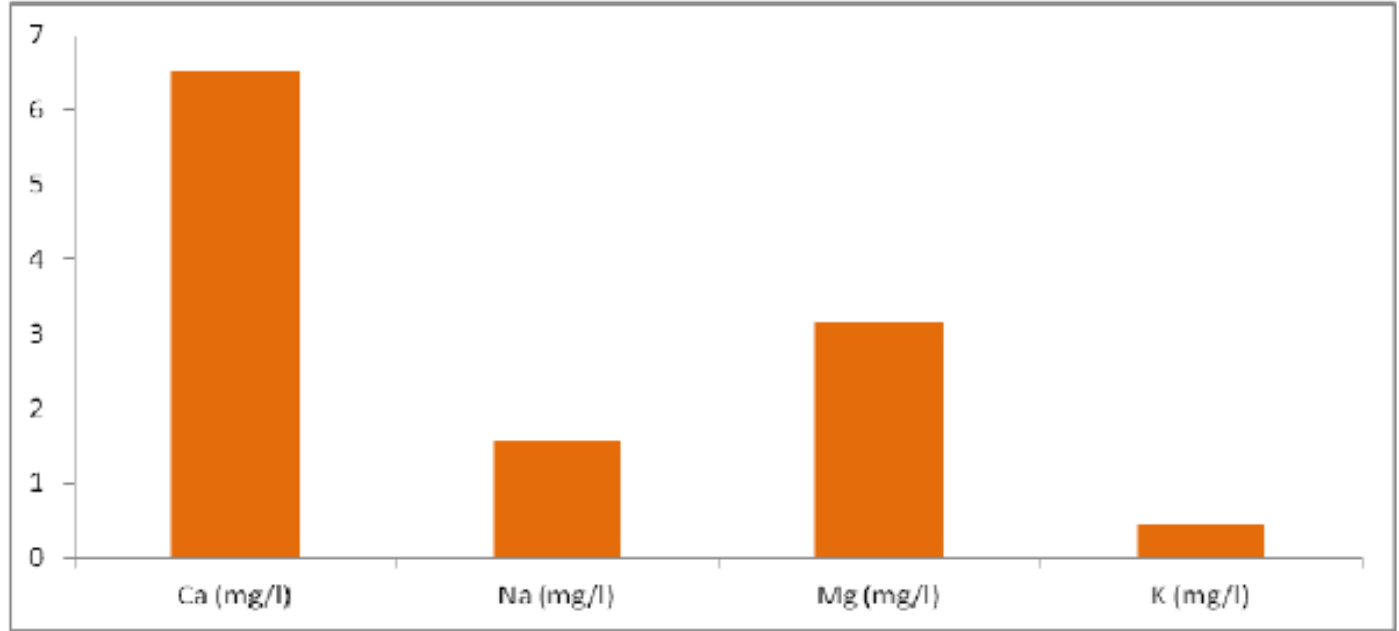

Figure 3 Cations concentrations in the Study Area

Spatial Variation of Groundwater Chemical Properties in the Study Area

Table 2 shows the variation of groundwater chemical properties. The major cations and anions in the groundwater in the study area show a spatial trend. The groundwater was highly acidic in Borokiri (UPE) and Moscow Rd 1 with a value of 3.84 and 4.5 respectively, slightly acidic in Woji and Elijiji Woji and weakly acidic in areas like Elekahia, Borokiri CSS Forces Avenue (Figure 4). Considering the spatial concentration of Chloride $(\mathrm{Cl})$, it was very high in Abuloma with a value of $710 \mathrm{mg} / \mathrm{l}$ while the least was experienced in
Rumuagholu with a value of $12 \mathrm{mg} / \mathrm{l}$ (Figure 5). Similarly, the concentration of Nitrate $\left(\mathrm{NO}_{3}{ }^{-}\right)$revealed that the highest was experienced in the Harley Street with a value of $34 \mathrm{mg} / \mathrm{l}$ while it was least in Rumuibekwe with a value of $0.01 \mathrm{mg} / \mathrm{l}$ (Table 2). Total Dissolved Solids (TDS) was highest at Marine Base with a value of $401 \mathrm{mg} / \mathrm{l}$ and least at Elekahia with a value of $21 \mathrm{mg} / 1$ (Figure 7). The salinity concentration was very high in Amadi Ama and Mgbuoba compared to other sampled areas with values of $511 \mathrm{ppt}$ and 672.75 ppt while the least was experienced in
Odili
Road
(Table
2)

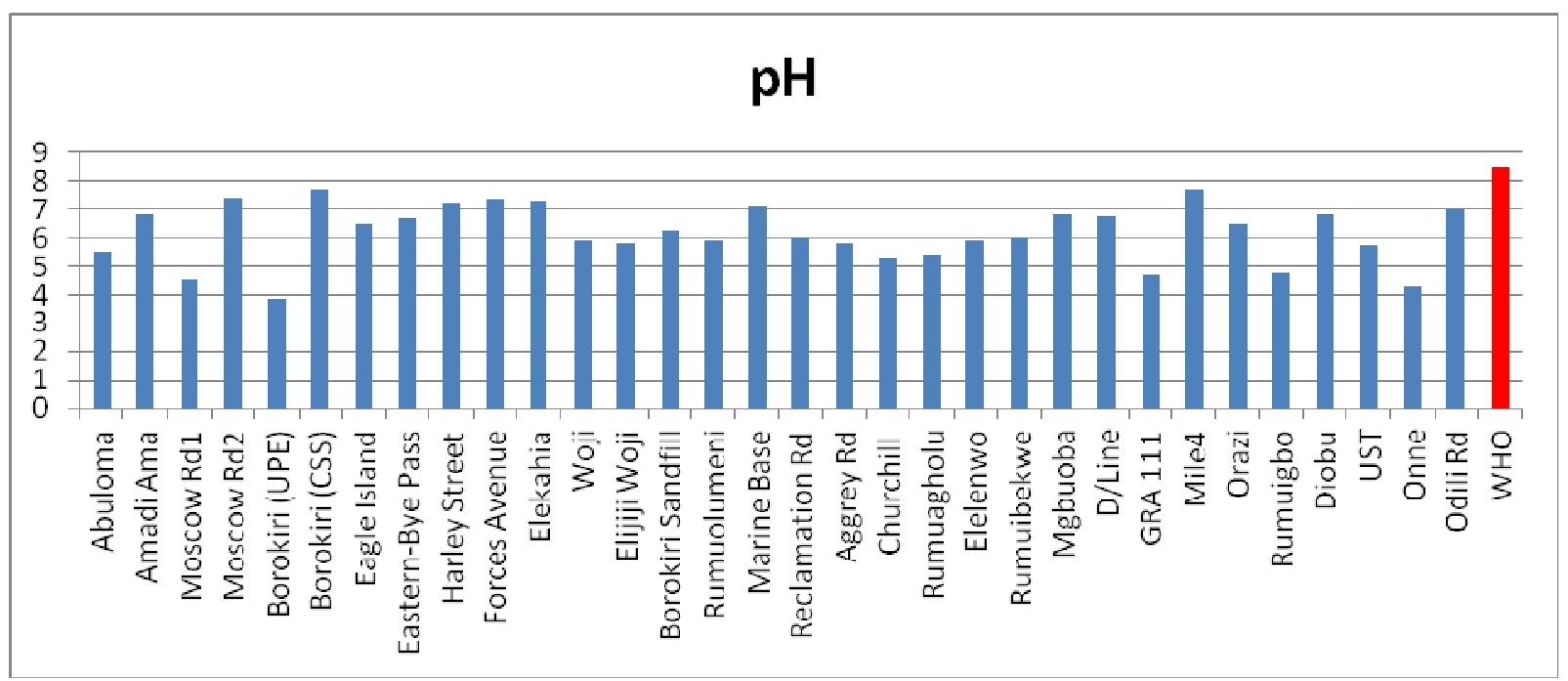

Figure $4 \mathrm{pH}$ concentration in the Study Area 


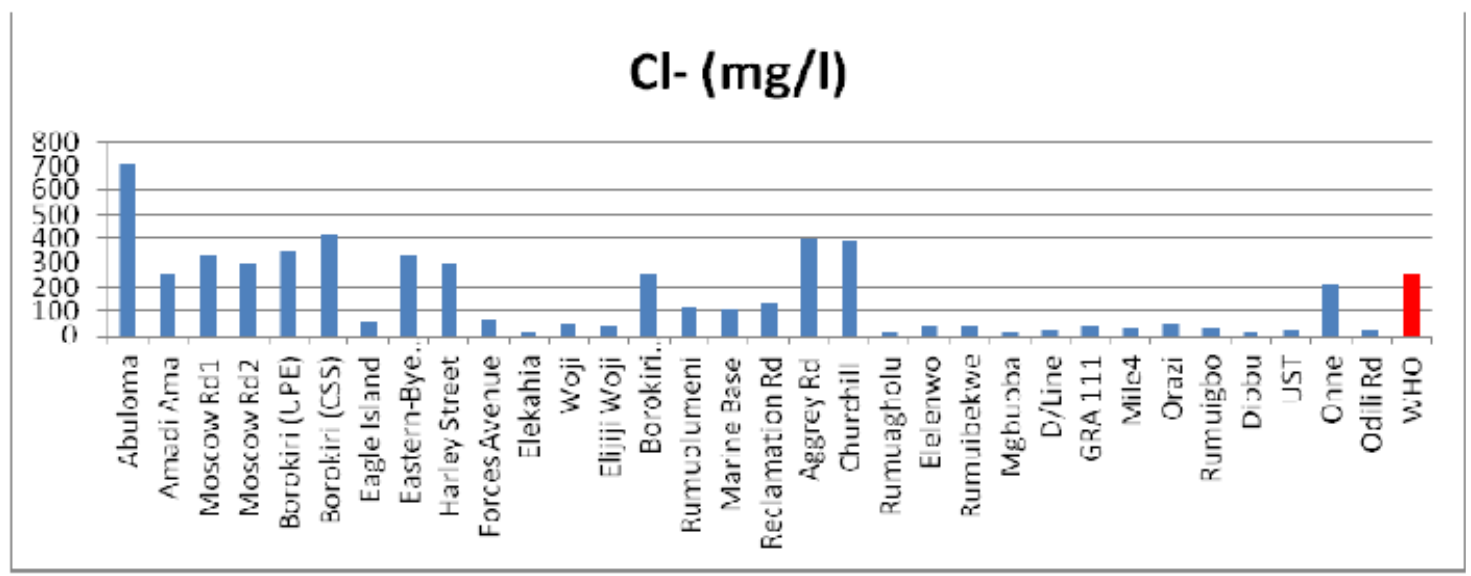

Figure 5 Chloride concentration in the Study Area

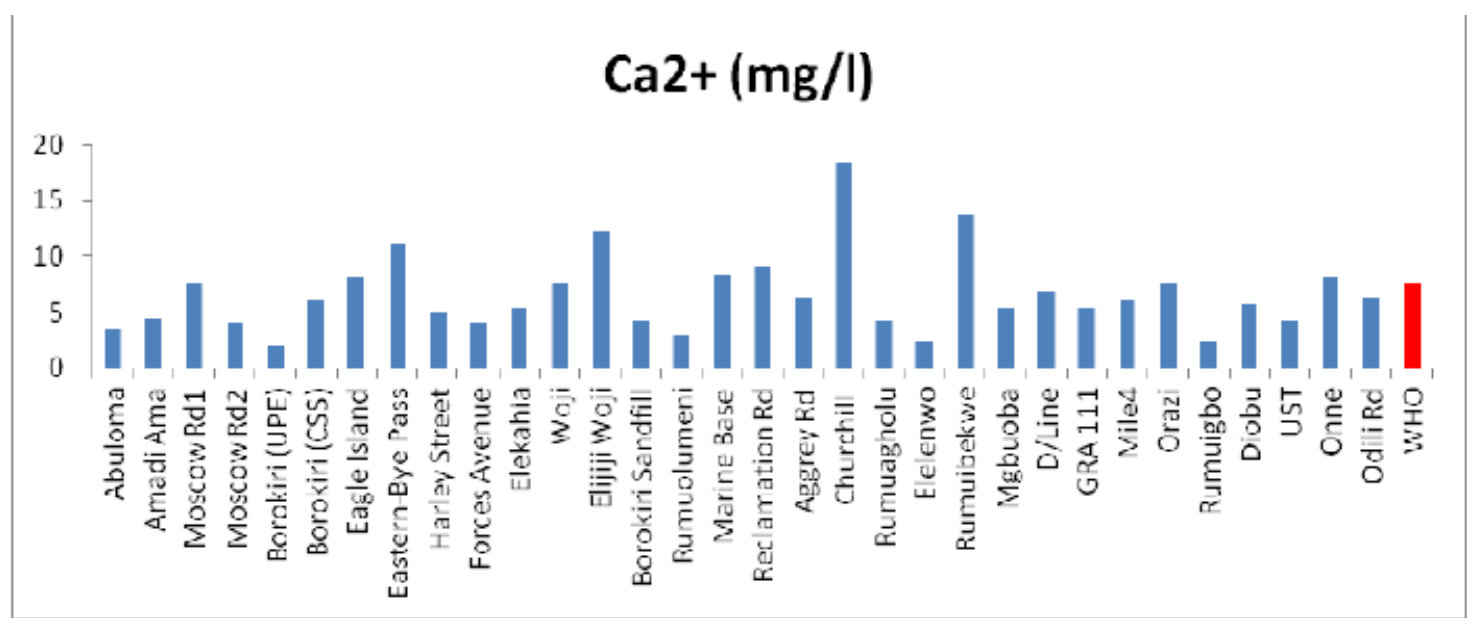

Figure 6 Calcium concentration in the Study Area

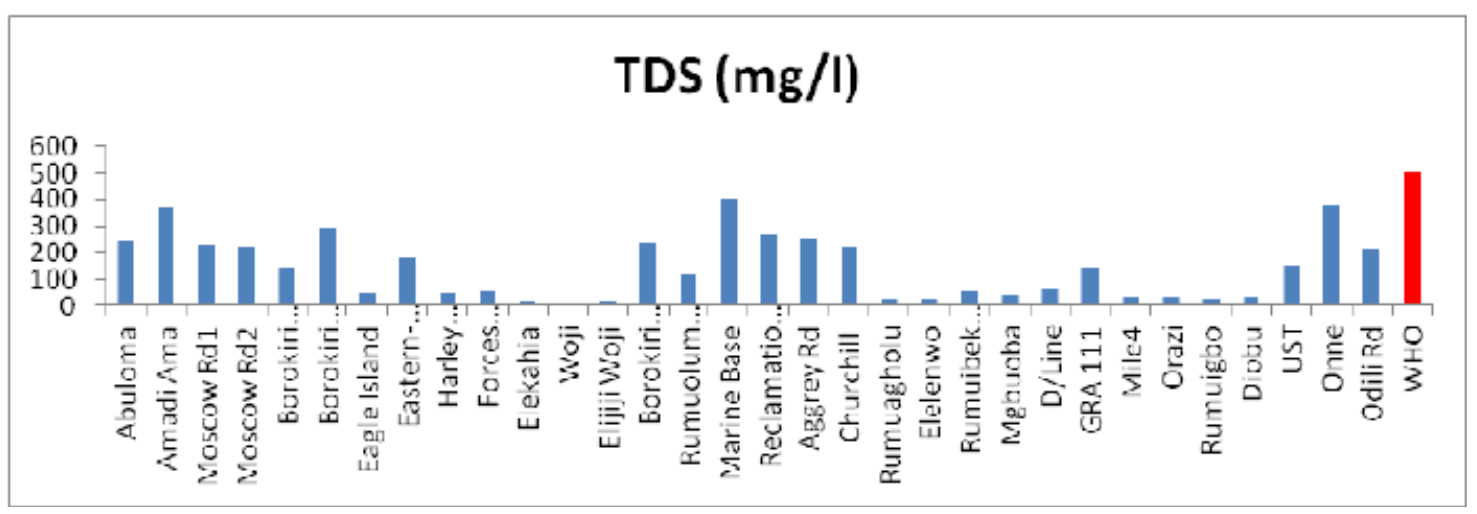

Figure 7 Total Dissolved Solids concentration in the Study Area 
Ethiopian Journal of Environmental Studies and Management EJESM Vol. 5 no.4 (Suppl.2) 2012

Table 2 Chemical Composition of Groundwater Samples

\begin{tabular}{|c|c|c|c|c|c|c|c|c|c|}
\hline Location & Temp $\left({ }^{\circ} \mathrm{C}\right)$ & $\mathrm{pH}$ & $\begin{array}{l}\text { EC } \\
(\mu \mathrm{S} / \mathrm{cm})\end{array}$ & $\begin{array}{l}\text { TDS } \\
(\mathrm{mg} / \mathrm{l})\end{array}$ & $\begin{array}{l}\mathrm{Cl}^{-} \\
(\mathrm{mg} / \mathrm{l})\end{array}$ & $\begin{array}{l}\mathrm{SO}_{4}^{2-} \\
(\mathrm{mg} / \mathrm{l})\end{array}$ & $\begin{array}{l}\text { Salinity } \\
\text { (ppt) }\end{array}$ & $\mathrm{NO}_{3}^{-}(\mathrm{mg} / \mathrm{l})$ & $\begin{array}{l}\mathrm{HCO}_{3}^{-} \\
(\mathrm{mg} / \mathrm{l})\end{array}$ \\
\hline Abuloma & 27.22 & 5.53 & 573 & 250 & 710 & ND & 116 & 0.23 & 18.401 \\
\hline Amadi Ama & 26.91 & 6.81 & 421.6 & 370.5 & 250 & ND & 511 & ND & 21.8 \\
\hline Moscow Rd1 & 27.02 & 4.5 & 522 & 230.6 & 330 & ND & 355 & 0.201 & 6.701 \\
\hline Moscow Rd2 & 28.33 & 7.4 & 513 & 221.3 & 300 & 75 & 82 & 0.831 & 10.321 \\
\hline Borokiri (UPE) & 26.51 & 3.84 & 717.4 & 142.7 & 351 & 19.3 & 181 & 0.51 & 21.01 \\
\hline Borokiri (CSS) & 29.03 & 7.72 & 618.2 & 297.2 & 410 & 90.1 & 163.4 & ND & 54.011 \\
\hline Eagle Island & 26.35 & 6.5 & 230 & 49 & 53 & 69.13 & 398.6 & ND & 11 \\
\hline Eastern-Bye Pass & 27.67 & 6.7 & 183.7 & 183.21 & 331 & 82.55 & 200.5 & 14 & 39.23 \\
\hline Harley Street & 29.03 & 7.23 & 195.2 & 55 & 300 & 96.32 & 85.1 & 34 & 3.003 \\
\hline Forces Avenue & 29.64 & 7.34 & 181.4 & 59.7 & 68 & 38.31 & 49.31 & 0.1 & 8.19 \\
\hline Elekahia & 28.28 & 7.3 & 33.5 & 21 & 18 & 87.15 & 240.11 & 6.5 & 12.11 \\
\hline Woji & 27.19 & 5.9 & 49.3 & 12.6 & 48 & 75.8 & 150 & 3.2 & 15.3 \\
\hline Elijiji Woji & 26.4 & 5.81 & 28 & 20 & 38 & ND & 50 & 0.31 & 58.04 \\
\hline Borokiri Sandfill & 27.92 & 6.23 & 429.3 & 241 & 250 & 48 & 113.21 & 6.3 & ND \\
\hline Rumuolumeni & 27.51 & 5.9 & 350.6 & 122.7 & 115 & 72.96 & 210.32 & 0.6 & 30 \\
\hline Marine Base & 26.83 & 7.11 & 560 & 401 & 103.5 & 22.03 & 63.7 & 13 & 7.11 \\
\hline Reclamation Rd & 26.33 & 6.02 & 527 & 270 & 132 & 24.7 & 25 & 9.311 & 9.5 \\
\hline Aggrey Rd & 27.04 & 5.83 & 150 & 255 & 401 & 230.1 & 15.6 & 0.5 & 15.21 \\
\hline Churchill & 28.27 & 5.31 & 160 & 218 & 390.5 & 9.7 & 62.1 & 0.1 & 20.713 \\
\hline Rumuagholu & 29.47 & 5.44 & 50 & 25 & 12 & 78 & 95.3 & 0.2 & 8.08 \\
\hline Elelenwo & 28.03 & 5.93 & 35 & 25 & 35 & 65.1 & 26.4 & 0.5 & 10.345 \\
\hline Rumuibekwe & 28.17 & 6.01 & 56 & 59 & 38 & 74.71 & 62.1 & 0.01 & 11 \\
\hline Mgbuoba & 26.78 & 6.82 & 32 & 39.3 & 19 & 96 & 672.75 & 1.55 & 13.4 \\
\hline D/Line & 28.51 & 6.76 & 49.42 & 65.6 & 23 & ND & 60.24 & 1.58 & 10.361 \\
\hline GRA 111 & 28.02 & 4.69 & 36.73 & 140.54 & 41 & 80 & 130.3 & 2 & 12.712 \\
\hline Mile4 & 27.3 & 7.71 & 30.21 & 33.6 & 30.8 & 70 & 220.5 & 5.32 & 15.17 \\
\hline Orazi & 28.03 & 6.5 & 74.01 & 36 & 50.51 & 78 & 120.12 & 0.4 & 12.121 \\
\hline Rumuigbo & 27.22 & 4.75 & 33 & 33 & 32 & 191.3 & 50 & 0.33 & 13.1 \\
\hline Diobu & 28 & 6.83 & 45 & 35.72 & 16.1 & 126 & 10.33 & 0.624 & 29.1 \\
\hline UST & 27.11 & 5.73 & 250.13 & 150.1 & 28 & 100 & 15.11 & 0.666 & 12 \\
\hline Onne & 28.13 & 4.28 & 519.4 & 381.31 & 215 & 80 & 12 & 0.378 & 12 \\
\hline Odili Rd & 27.1 & 7 & 210.28 & 211 & 28.13 & 120.3 & 10 & 0.507 & 12.3 \\
\hline WHO (2006) & NS & $\begin{array}{l}6.5- \\
8.5 \\
\end{array}$ & 500 & 500 & 250 & 250 & NS & 50 & NS \\
\hline $\mathrm{Ca}^{2+}(\mathrm{mg} / \mathrm{l})$ & \multicolumn{4}{|c|}{$\mathrm{Na}^{+}(\mathrm{mg} / \mathrm{l})$} & \multicolumn{2}{|c|}{$\mathrm{Mg}^{2+}(\mathrm{mg} / \mathrm{l})$} & \multicolumn{3}{|c|}{$\mathrm{K}^{+}(\mathrm{mg} / \mathrm{l})$} \\
\hline \multicolumn{2}{|c|}{3.46} & \multicolumn{3}{|c|}{2.756} & \multicolumn{3}{|c|}{2.222} & \multicolumn{2}{|c|}{0.54} \\
\hline \multicolumn{2}{|c|}{4.444} & \multicolumn{3}{|c|}{3} & \multicolumn{3}{|c|}{2.981} & \multicolumn{2}{|c|}{0.81} \\
\hline \multicolumn{2}{|c|}{7.633} & \multicolumn{3}{|c|}{1.022} & \multicolumn{3}{|c|}{0.826} & \multicolumn{2}{|c|}{0.505} \\
\hline \multicolumn{2}{|c|}{4.111} & \multicolumn{3}{|c|}{0.834} & \multicolumn{3}{|c|}{4.5} & 0 & \\
\hline & & & 0.666 & & & 2.757 & & 0.8 & \\
\hline & & & 3.4 & & & 0.445 & & 0.4 & \\
\hline & & & 1.4 & & & 0.233 & & 0.7 & \\
\hline & & & 1.776 & & & 2.08 & & 0.1 & \\
\hline & & & 1.822 & & & 1 & & 0.6 & \\
\hline & & & 0.31 & & & 3.221 & & 0.4 & \\
\hline & & & 0.433 & & & 0.31 & & 0 & \\
\hline & & & 1.777 & & & 0.277 & & 0.4 & \\
\hline & & & 2.433 & & & 0.823 & & 0 & \\
\hline & & & 2.321 & & & 1.789 & & 0.4 & \\
\hline & & & 1.443 & & & 5.677 & & 0.5 & \\
\hline & & & 2.32 & & & 2.111 & & 0.6 & \\
\hline & & & 1 & & & 4.577 & & 0.3 & \\
\hline
\end{tabular}




\begin{tabular}{cccc}
\hline 6.322 & 2.303 & 8.9 & 0.231 \\
18.3 & 1.82 & 7 & 0.322 \\
4.245 & 2.211 & 2.821 & 0.788 \\
2.478 & 0.213 & 0.332 & 0.133 \\
13.788 & 0.241 & 4.3 & 0.567 \\
5.333 & 1.444 & 2.781 & 0.044 \\
6.781 & 2.3 & 4 & 0.781 \\
5.34 & 1 & 8.721 & 0.233 \\
6 & 3.445 & 3.01 & 0.457 \\
7.586 & 2.111 & 2.111 & 0.543 \\
2.3 & 0.333 & 6.2 & 0.789 \\
5.777 & 2.113 & 5.833 & 0.233 \\
4.234 & 0.631 & 4.05 & 0.54 \\
8 & 1.376 & 2.341 & 0.22 \\
6.333 & 0.311 & 3 & 0.567 \\
7.5 & 200 & 50 & 200 \\
\hline
\end{tabular}

(NS = Not Stated), (ND = Not Detected)

Mapping the groundwater parameters

The 3D and 2D representation of depth of the sampled boreholes, the groundwater $\mathrm{pH}$, Chloride Calcium and TDS were mapped using geostatistics method (kriging) to determine the spatial variation of these groundwater parameters (Figures. 9, 10, 11, 12,13 and 14). It is evident that boreholes varied with depth in different areas in the study area. This could cause differentials in the groundwater parameter dynamics.

\section{Relationship between Depth and Groundwater parameters \\ Depth and $\mathrm{pH}$}

The regression analysis was carried out between the depth of the borehole and $\mathrm{pH}$ of the groundwater of the study area. The analysis carried out in Idrisi for Windows using REGRESS module revealed that the $r=$ -0.467433 and the coefficient of determination is $21.55 \%$. This shows that the groundwater $\mathrm{pH}$ and depth has a moderately inverse relationship and depth can only explain $21.55 \%$ of the variation in the $\mathrm{pH}$. The regression model generated from the relationship is $\mathrm{Y}_{\mathrm{pH}}=6.639463-$ $0.007433 \mathrm{X}_{\mathrm{DEPTH}}$.

\section{Depth and Calcium}

The relationship exhibited between depth and Calcium using regression analysis revealed that the $r=$ is -0.167219 and the coefficient of determination is $2.80 \%$. The regression model generated is $\mathrm{Y}_{\mathrm{Ca}}=7.579467$ $-0.010366 \mathrm{X}_{\text {DEPTH }}$. This shows also that both depth and Calcium concentration in the study area exhibited an inverse relationship and the depth could only explain $2.80 \%$ of the concentration in Calcium.

\section{Conclusion}

In this study, the application of GIS in analyzing groundwater in Port Harcourt Metropolis has been properly demonstrated in ArcGIS, Idrisi and Surfer programs. The borehole locations were mapped and the spatial variation in some selected ones was also revealed. Furthermore, the spatial relationship using regression analysis also revealed that the relationship between $\mathrm{pH}$ and Calcium exhibited an inverse relationship with depth. It is therefore recommended that periodic monitoring and assessing groundwater in the study area should be encouraged especially through the use of GIS. This will bring about easy updating of groundwater data. 
Ethiopian Journal of Environmental Studies and Management EJESM Vol. 5 no.4 (Suppl.2) 2012

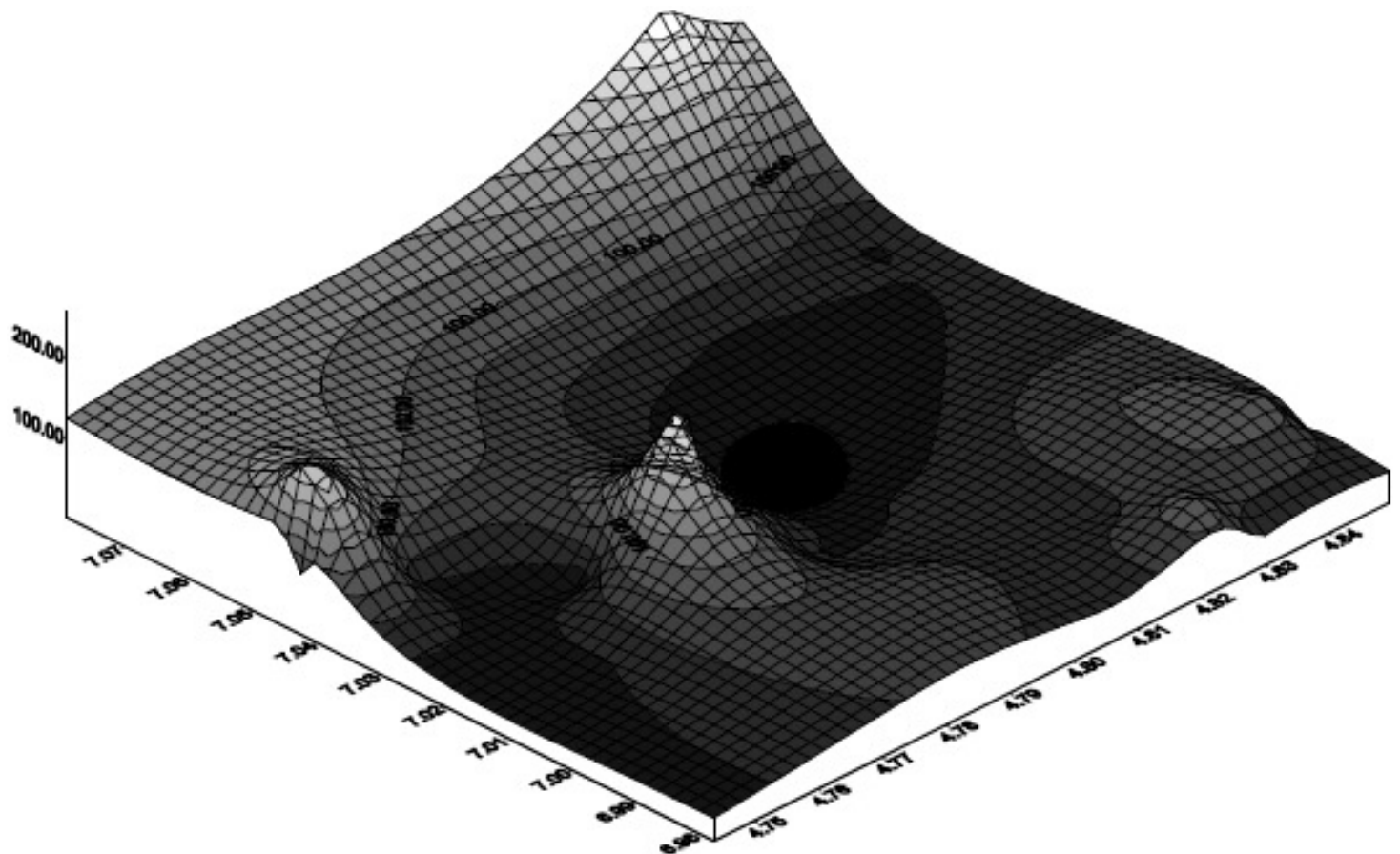

Figure 9 The 3D-representation of Borehole Depth

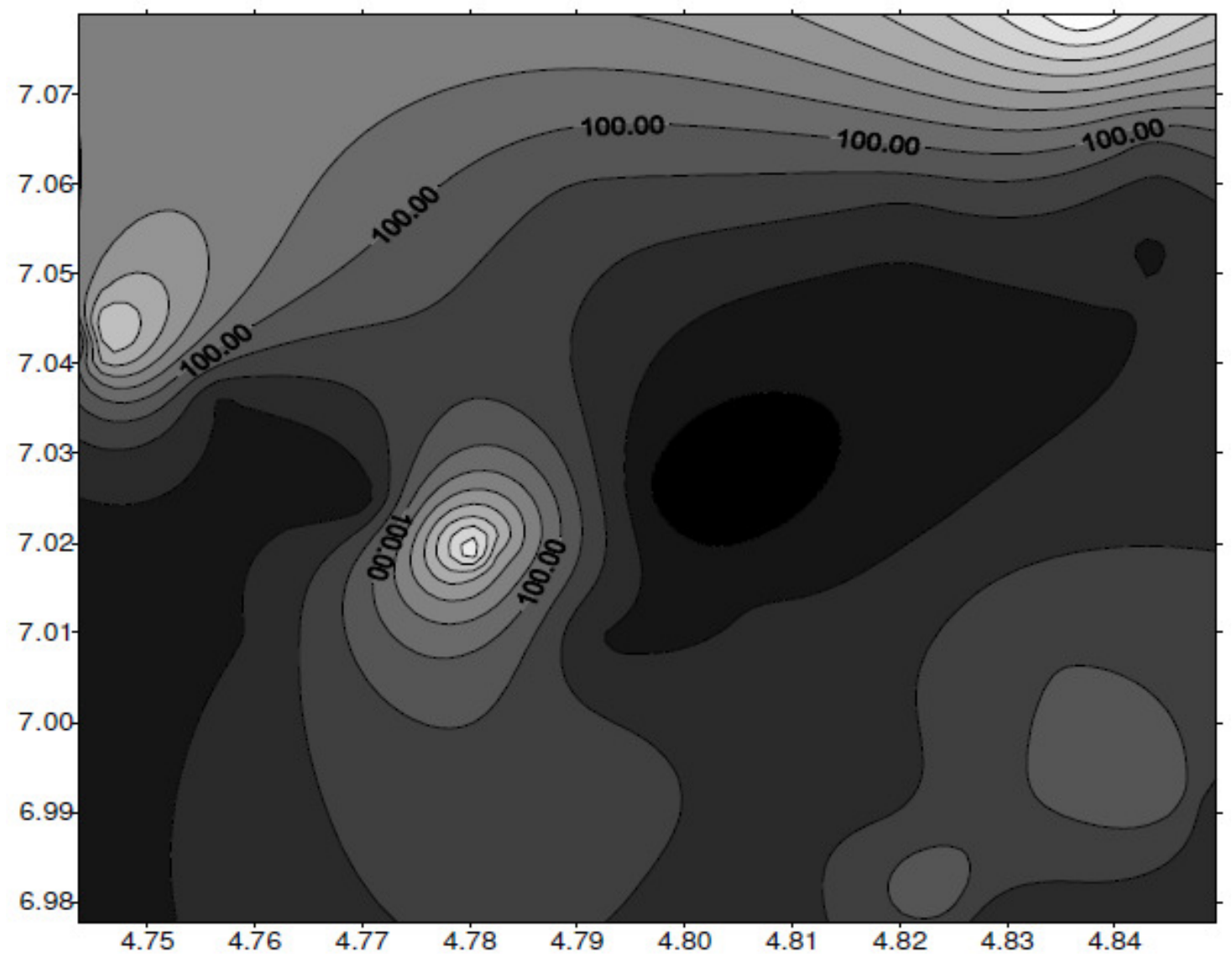

Figure 10 2D-representation of Borehole Depths 
Groundwater Quality Assessment \& Monitoring............Nwankwoala et al. EJESM Vol. 5 no.4 (Suppl.2) 2012

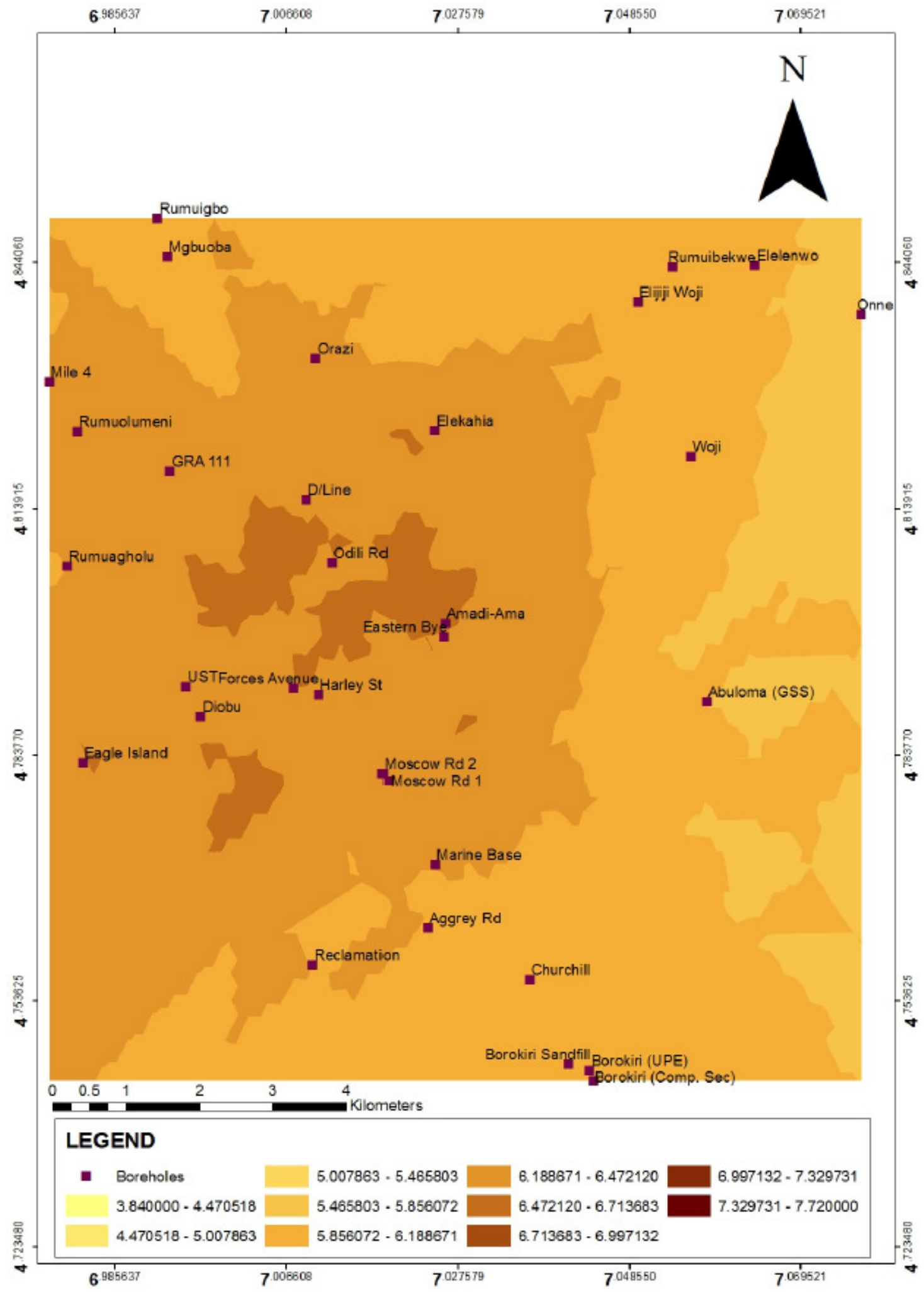

Figure $11 \mathrm{pH}$ variability in the groundwater in Port Harcourt Metropolis 
Ethiopian Journal of Environmental Studies and Management EJESM Vol. 5 no.4 (Suppl.2) 2012

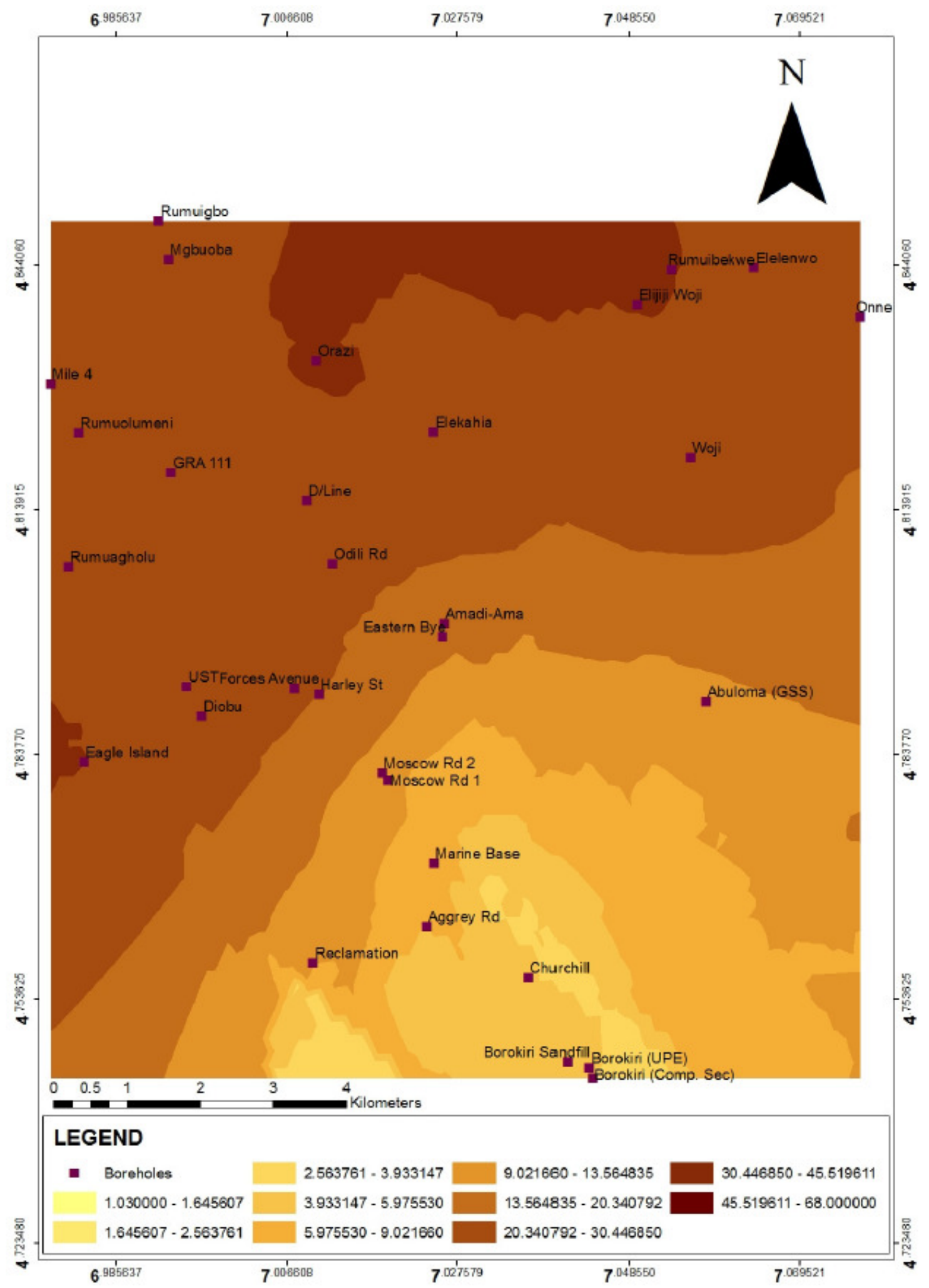

Figure 12 Chloride Variability of groundwater in Port Harcourt Metropolis 
Groundwater Quality Assessment \& Monitoring............Nwankwoala et al. EJESM Vol. 5 no.4 (Suppl.2) 2012

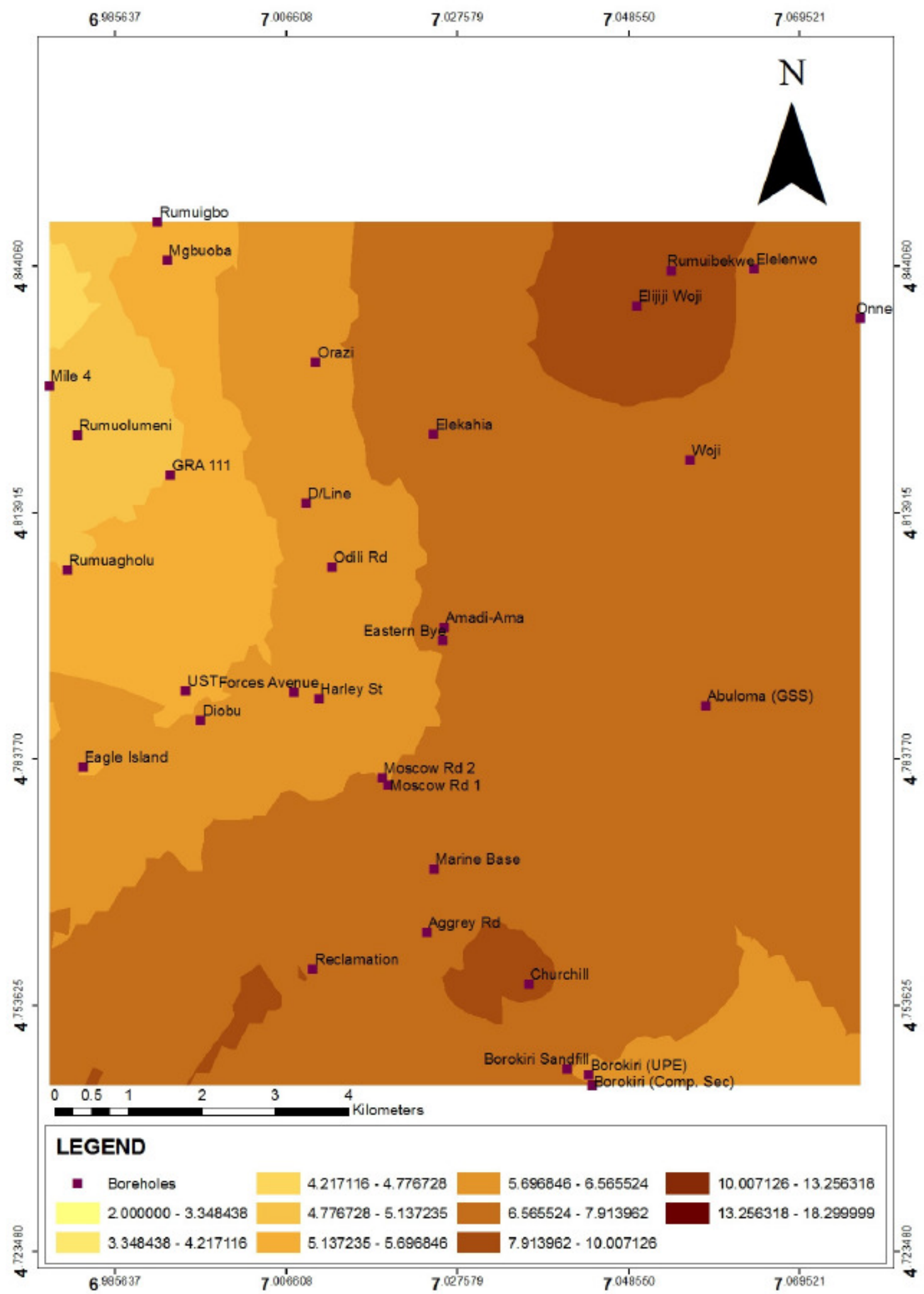

Figure 13 Calcium Variability of groundwater in Port Harcourt Metropolis 
Ethiopian Journal of Environmental Studies and Management EJESM Vol. 5 no.4 (Suppl.2) 2012

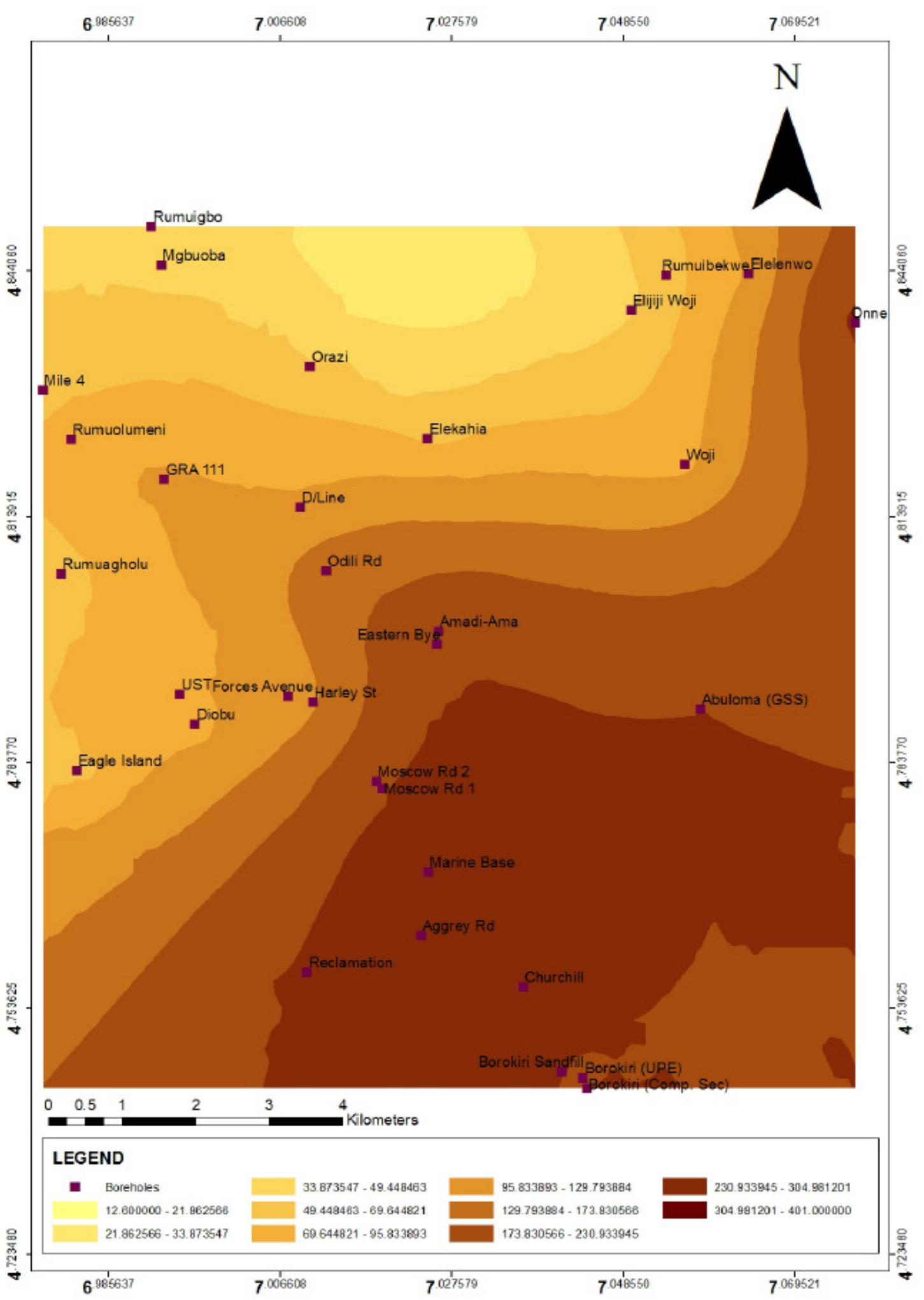

Figure 14 Total Dissolved Solids of groundwater in Port Harcourt 


\section{References}

Aral, M. M. and Maslia, M. L. (1996), Evaluation of human exposure to contaminated water supplies using GIS and modelling. Kovar K., Nachtnebel, H. P. (Eds.): Application of geographic information systems in hydrology and water resources management. IAHS Publication, 235-243

Christophoridis, C., Bizani, E. and Fytianos, K. (2000), Environmental Quality Monitoring, Using GIS as a Tool of Visualization, Management and Decision-Making: Applications Emerging from the EU Water Framework Directive EU 2000/60.

Goodchild, M. F. (2000), Communicating geographic information in a digital age. Annals of American Geographers pp2-355.

Krishnamurthy, J., Kumar, N.V., Jayaraman, V. and Manivel, M. (1996), An approach to demarcate groundwater potential zones through remote sensing and a geographic information system. Int. J Remote Sens, $17,1867-1885$.

lloeje, N.P. (1972), A New Geography of West Africa, Longman Group Limited, Nigeria.

Mogheir, Y. and Singh, V.P. (2002), Application of Information Theory to
Groundwater Quality Monitoring Networks. Water Resources Management 16, 37-49.

Nwankwoala, H.O. and Udom, G.J. (2011), Studies on Major ion Chemistry and Hydrogeochemical Processes of Groundwater in Port Harcourt City, Southern- Nigeria. Journal of Spatial Hydrology, 11(1), 1-16.

Saraf, A.K. and Choudhury, P.R. (1998), Integrated remote sensing and GIS for groundwater exploration and identification of artificial recharge sites. Int. J. Remote Sens 19, $1825-1841$

Solomon, S. and Quiel, F. (2006), Groundwater study using remote sensing and geographic information systems (GIS) in the central highlands of Eritrea. Hydrogeology Journal, 14, 729 - 741

Tripathy G.K. and Jothimani, P. (2000), Monitoring Water Pollution. GIS Developemnt-Asia Pacific. (www.gisdevelopment.com assessed on the $19^{\text {th }}$ October, 2011).

Usali, N. and Ismail, M.H. (2010). Use of Remote Sensing and GIS in Monitoring Water Quality. Journal of Sustainable Development, 3(3), 228-238. 